\title{
PENINGKATAN PROFESIONALITAS GURU MATEMATIKA MELALUI PENULISAN KARYA ILMIAH
}

\author{
Ida Nuraida, Ai Tusi Fatimah, Nur Eva Zakiah* \\ Universitas Galuh \\ *Email: nureva.math@gmail.com \\ (Diterima 03-03-2020; Disetujui 24-03-2020)
}

\begin{abstract}
ABSTRAK
Kegiatan pengabdian yang telah dilaksanakan berupa kegiatan workshop dengan judul "Peningkatan Profesionalitas Guru Matematika melalui Penulisan Karya Ilmiah". Sasaran kegiatan workshop ini adalah guru matematika di Desa Padamulya dan Desa Sukamaju Kecamatan Cihaurbeuti Kabupaten Ciamis. Hal ini dilatarbelakangi karena guru dituntut melakukan penelitian tindakan kelas untuk meningkatkan kualitas pembelajaran dalam mata pelajaran yang diampunya. Kegiatan workshop dihadiri oleh 30 orang guru dari Dinas Pendidikan dan Kementerian Agama Kabupaten Ciamis. Tujuan dilaksanakan kegiatan workshop ini adalah untuk memberi pemahaman dan memotivasi guru untuk melakukan penulisan karya ilmiah dalam bentuk Penelitian Tindakan Kelas (PTK). Pendekatan yang digunakan dalam kegiatan pengabdian ini bersifat persuasif-edukatif, yang dimaksudkan untuk memberikan pengetahuan, pemahaman dan keterampilan dalam penulisan karya ilmiah. Adapun metode yang digunakan adalah ceramah, diskusi, demonstrasi, dan simulasi/praktek. Hasil yang diperoleh dari kegiatan workshop ini yaitu guru-guru mampu: (1) mendeskripsikan kondisi ideal dan kondisi nyata berdasarkan hasil observasi; (2) merumuskan masalah berdasarkan hasil observasi; (3) merumuskan proposal dan membuat solusi pemecahan masalah; (4) melaksanakan PTK; dan (5) merumuskan dan mempresentasikan laporan pelaksanaan PTK.
\end{abstract}

Kata kunci: Penelitian Tindakan Kelas, Penulisan Karya Ilmiah, Profesionalitas Guru

\section{PENDAHULUAN}

Sistem Pendidikan Nasional dalam Pasal 39 UU RI No. 20 Tahun 2003 menyatakan bahwa pendidik merupakan tenaga profesional yang bertugas merencanakan dan melaksanakan proses pembelajaran, menilai hasil pembelajaran, melakukan pembimbingan dan pelatihan, serta melakukan penelitian dan pengabdian kepada masyarakat, terutama pada pendidik di perguruan tinggi. Lebih tegas dijelaskan dalam Pasal 1 bahwa guru adalah pendidik profesional dengan tugas utama mendidik, mengajar, membimbing, mengarahkan, melatih, menilai, dan mengevaluasi peserta didik pada pendidikan usia dini jalur pendidikan formal, pendidikan dasar dan menengah.

Seorang guru dianggap profesional apabila mampu mengerjakan tugas dengan selalu berpegang teguh pada etika profesi, independen, produktif, efektif, efisien dan inovatif serta didasarkan pada prinsip-prinsip pelayanan prima yang didasarkan pada unsur-unsur ilmu atau teori yang sistematis, kewenangan profesional, pengakuan masyarakat, dan kode etik yang regulatif. Sehingga guru profesional dituntut untuk terus-menerus berkembang sesuai dengan perkembangan zaman, ilmu pengetahuan, dan teknologi, serta kebutuhan masyarakat termasuk kebutuhan terhadap sumber daya manusia yang berkualitas dan memiliki 
Peningkatan Profesionalitas Guru Matematika Melalui Penulisan Karya Ilmiah

Ida Nuraida, Ai Tusi Fatimah, Nur Eva Zakiah

kapabilitas untuk mampu bersaing di forum regional, nasional, ataupun internasional (Sukanti, 2008).

Pasal 20 ayat b Undang-Undang Republik Indonesia Nomor 14 Tahun 2005 tentang Guru dan Dosen menyebutkan dalam melaksanakan tugas keprofesionalan, guru berkewajiban mengembangkan kualifikasi akademik dan kompetensi secara berkelanjutan sejalan dengan perkembangan ilmu pengetahuan, teknologi dan ilmu. Undang-undang ini menyebutkan bahwa profesi guru sebagai profesi yang sejajar dengan dosen di perguruan tinggi.

Guru harus terus berupaya mengembangkan profesinya yaitu dengan cara pengembangan kompetensi guru yang dilaksanakan sesuai dengan kebutuhan, bertahap, berkelanjutan untuk meningkatkan profesionalitasnya. Pengembangan profesi guru dapat dilakukan dengan melakukan penulisan karya ilmiah, hal ini merupakan kegiatan yang sangat penting bagi seorang guru yang profesional. Kegiatan ini tidak saja perlu dilakukan dalam rangka memperoleh angka kredit untuk kenaikan jabatan atau untuk keperluan sertifikasi, tetapi terlebih lagi perlu dilakukan dalam rangka peningkatan kualitas pengelolaan kelas, kualitas layanan kepada anak didik, dan juga peningkatan profesionalitas guru itu sendiri.

Usman (2006) memberikan suatu kesimpulan bahwa suatu pekerjaan yang bersifat profesional memerlukan beberapa bidang ilmu yang secara sengaja harus dipelajari dan kemudian diaplikasikan bagi kepentingan umum. Kata profesional itu sendiri berasal dari kata sifat yang berarti pencaharian dan sebagai kata benda yang berarti orang yang mempunyai keahlian seperti guru, dokter, hakim, dan sebagainya. Dengan kata lain, pekerjaan yang bersifat profesional adalah pekerjaan yang hanya dapat dilakukan oleh mereka yang khusus dipersiapkan untuk itu dan bukan pekerjaan yang dilakukan oleh mereka yang karena tidak dapat memperoleh pekerjaan lain. Selanjutnya disimpulkan bahwa profesionalitas adalah sebutan terhadap kualitas sikap para anggota suatu profesi terhadap profesinya serta derajat pengetahuan dan keahlian yang mereka miliki untuk dapat melakukan tugas-tugasnya.

Kompetensi yang harus dimiliki oleh seorang guru yang profesional menurut Mulyasa (2008) mencakup empat aspek yaitu (1) kompetensi pedagogik; (2) kompetensi kepribadian; (3) kompetensi profesional; dan (4) kompetensi sosial.

Mulyasa (2008) menyatakan bahwa guru profesional harus memiliki persyaratan, yang meliputi: (1) memiliki bakat sebagai guru; (2) memiliki keahlian sebagai guru; (3) memiliki keahlian yang baik dan terintegrasi; (4) memiliki mental yang sehat; (5) berbadan sehat; (6) 
memiliki pengalaman dan pengetahuan yang luas; (7) guru adalah manusia berjiwa Pancasila; dan (8) guru adalah seorang warga negara yang baik.

Nampaknya, sampai saat ini terdapat banyak faktor yang menyebabkan kondisi dimana belum banyak guru yang melakukan penulisan karya ilmiah. Diantara faktor yang menghambat dalam penulisan karya ilmiah adalah kemauan dan kemampuan guru untuk melakukan penelitian, serta menyajikan hasil penelitiannya.

Solusi untuk mengatasi faktor penghambat tersebut diantaranya perlu diadakan suatu kegiatan untuk memberikan motivasi, pemahaman dan gambaran tentang penulisan karya ilmiah. Bentuk kegiatan tersebut akan lebih bermakna dengan menghasilkan suatu produk, yaitu kegiatan yang diselenggarakan dalam bentuk workshop.

Setelah mengikuti kegiatan workshop, diharapkan guru-guru menjadi produktif dalam menghasilkan karya tulis ilmiah guna meningkatkan profesionalitasnya. Dengan tumbuhnya kemauan guru untuk menulis, hal ini akan meningkatkan pengetahuan dan wawasan guru karena terdorong untuk mengumpulkan dan mempelajari bahan-bahan dari berbagai sumber terkait dengan apa yang akan ditulisnya. Hal ini tentu saja akan menunjang pengembangan kompetensi guru, khususnya penguasaan ilmu pengetahuan yang menjadi bidangnya.

Tuntutan untuk menulis karya ilmiah bagi guru terutama melakukan Penelitian Tindakan Kelas (PTK) didasarkan pada Peraturan Menteri Pendidikan Nasional Nomor 16 Tahun 2007 tentang Standar Kualifikasi Akademik dan Kompetensi Guru. Berdasarkan peraturan tersebut nomor 10.3 menyatakan bahwa guru melakukan penelitian tindakan kelas untuk meningkatkan kualitas pembelajaran dalam mata pelajaran yang diampu. Selanjutnya nomor 23.3 menyatakan bahwa guru melakukan penelitian tindakan kelas untuk peningkatan keprofesionalan. Oleh karena itu, menjadi suatu keharusan bagi guru profesional untuk melakukan penelitian tindakan kelas dengan tujuan meningkatkan kualitas pembelajaran dan menghasilkan lulusan yang berkualitas (Kunandar, 2013).

Berdasarkan uraian di atas, perlu dilakukan kegiatan workshop penulisan karya ilmiah bagi para guru yang difokuskan melakukan penelitian khusunya penelitian tindakan kelas. Diharapkan dengan terlaksananya kegiatan tersebut dapat memberikan pemahaman tentang jenis-jenis dan teknik penulisan karya ilmiah serta memberi gambaran praktis Penelitian Tindakan Kelas (PTK). 


\section{BAHAN DAN METODE}

Kegiatan workshop ini dilakukan untuk memberi pemahaman tentang mekanisme penulisan karya tulis ilmiah dan memotivasi guru untuk melakukan penulisan karya ilmiah. Penulisan karya ilmiah merupakan kegiatan yang sangat penting dilakukan bagi seorang guru yang profesional.

Pendekatan yang digunakan dalam kegiatan pengabdian ini bersifat persuasif-edukatif, yaitu dimaksudkan untuk memberikan pengetahuan, pemahaman, dan keterampilan dalam penulisan karya ilmiah. Adapun metode yang digunakan adalah ceramah, diskusi, demonstrasi, dan praktek/latihan. Adapun tahapan-tahapan kegiatan pengabdian sebagai berikut:

1. Metode ceramah dan diskusi disampaikan pada waktu menjelaskan materi pengertian, jenis-jenis dan teknik penulisan karya ilmiah.

2. Metode demonstrasi dan praktek digunakan pada waktu menjelaskan penelitian tindakan kelas.

Penyusunan program kegiatan didasarkan atas program yang telah dijadwalkan. Adapun hal-hal yang dipersiapkan meliputi:

1. Survei/penjajakan di lapangan. Survei dilakukan di Desa Padamulya dan Desa Sukamaju Kecamatan Cihaurbeuti. Hal ini bertujuan untuk mengetahui dan memahami situasi dan kondisi setempat serta keadaan mengenai waktu penyelenggaraan kegiatan workshop.

2. Mempersiapkan materi/topik bahasan untuk workshop, meliputi:

a. Pengertian, jenis-jenis, dan tenik penulisan karya ilmiah.

b. Simulasi penulisan PTK.

3. Mempersiapkan tim pelaksana, yang terdiri atas dosen-dosen di Program Studi Pendidikan Matematika, yaitu 1 orang ketua pelaksana, 2 orang anggota pelaksana, dan dibantu oleh 3 orang mahasiswa sebagai tim teknis kegiatan.

Sasaran dari kegiatan workshop ini yaitu guru matematika di Desa Padamulya dan Desa Sukamaju Kecamatan Cihaurbeuti Kabupaten Ciamis. Peserta dibatasi sebanyak 30 orang yang berada di bawah naungan Dinas Pendidikan dan Kementerian Agama Kabupaten Ciamis, yang diharapkan dapat menularkan keterampilan yang dimilikinya, baik pada teman sejawatnya atau pada guru pengampu mata pelajaran lainnya. 


\section{HASIL DAN PEMBAHASAN}

Hasil dari kegiatan workshop ini diperoleh berdasarkan hasil observasi, hasil monitoring, dan hasil kuesioner terhadap pelaksanaan PTK, yaitu:

\section{Hasil Observasi Kegiatan Workshop}

Berdasarkan hasil observasi diketahui bahwa peserta workshop:

a. Mengikuti aktivitas kegiatan workshop dengan baik.

b. Aktif mengemukakan pendapat/bertanya.

c. Mampu memberikan berbagai contoh rmasalah untuk dikaji dalam PTK.

d. Menunjukkan antusias yang baik selama kegiatan.

e. Memanfaatkan waktu secara baik pada waktu kegiatan simulasi.

f. Mengikuti petunjuk simulasi pelaksanaan PTK dengan baik.

\section{Hasil Monitoring Pelaksanaan PTK}

Berdasarkan hasil monitoring pelaksanaan PTK diperoleh hasil bahwa peserta workshop:

a. Menerapkan cara berpikir ilmiah dalam pelaksanaan PTK.

b. Melaksanakan observasi secara visual atau menggunakan teknologi tentang persoalan nyata dan praktis mengenai fenomena pembelajaran dalam kelas.

c. Mengelola informasi dan data yang diperoleh dari kegiatan observasi pendahuluan baik dalam bentuk rekaman, foto, gambar, grafik, tabel berdasarkan sifat yang sejenis.

d. Merumuskan masalah dan membuat prediksi solusi alternatif dalam peningkatan mutu belajar mengajar.

e. Merancang dan melaksanakan tindakan kelas sebagai tindakan perbaikan mutu melalui pelaksanaan pekerjaan tugas sehari-hari untuk membuktikan bahwa alternatif solusi dapat diterima atau tidak dapat diterima.

f. Mengevaluasi tindakan kelas, membandingkan hasil studi lapangan dengan teori.

g. Menggunakan fakta, gambar, foto, grafik, catatan, untuk menguji langkah penelitian telah dilakukan dengan benar dan alternatif solusi.

h. Menyusun dan menyajikan laporan dalam bentuk karya tulis ilmiah.

i. Menerapkan hasil penemuan baru dalam rangka perbaikan mutu. 


\section{Hasil Kuesioner Kegiatan Workshop}

Hasil kuesioner dapat dilihat pada Tabel 1.

Tabel 1. Rangkuman Hasil Kuesioner

\begin{tabular}{|c|c|c|c|}
\hline No & Nama Peserta & Instansi & Komentar \\
\hline 1. & Iis Kuraesin, S.Pd. & MA Padamulya & $\begin{array}{l}\text { Pelaksanaan workshop semakin menambah } \\
\text { informasi tentang penulisan karya ilmiah } \\
\text { (PTK) dalam pembelajaran matematika. }\end{array}$ \\
\hline 2. & $\begin{array}{l}\text { Nunung Nurhayati, } \\
\text { S.Pd. }\end{array}$ & $\begin{array}{l}\text { SDN } 2 \\
\text { Padamulya }\end{array}$ & $\begin{array}{l}\text { Kegiatan workshop ini sangat bagus, lebih } \\
\text { memotivasi untuk melaksanakan PTK. } \\
\text { Karena ternyata melakukan PTK itu mudah. } \\
\text { Kegiatan seperti ini dapat meningkatkan } \\
\text { kompetensi sebagai pendidik. }\end{array}$ \\
\hline 3. & Drs. Dede Ali & MTs Padamulya & $\begin{array}{l}\text { Agendakan kerjasama dengan pihak } \\
\text { sekolah (minimal } 1 \text { kali dalam setahun), } \\
\text { karena secara tidak langsung telah meng- } \\
\text { upgrade para guru matematika, khususnya } \\
\text { di tingkat SMP. }\end{array}$ \\
\hline 4. & Riky. M, S.Pd. & $\begin{array}{l}\text { SMP Islam } \\
\text { Padamulya }\end{array}$ & $\begin{array}{l}\text { Alhamdulillah, kegiatan workshop ini } \\
\text { menjadi pengalaman baru bagi saya. Karena } \\
\text { saya baru berprofesi sebagai guru. Kegiatan } \\
\text { ini memotivasi saya untuk melakukan } \\
\text { penelitian guna meningkatkan hasil belajar } \\
\text { matematik siswa. }\end{array}$ \\
\hline 5. & Eti Latifah, S.Pd. & SDN 1 Sukamaju & $\begin{array}{l}\text { Terima kasih kepada seluruh pelaksana } \\
\text { kegiatan ini, materinya sangat menarik. Ini } \\
\text { memang bukan ilmu baru bagi saya, tapi ini } \\
\text { akan semakin memotivasi saya untuk } \\
\text { melakukan PTK dengan tujuan peningkatan } \\
\text { kualitas pembelajaran di kelas. }\end{array}$ \\
\hline 6. & $\begin{array}{l}\text { Nanang Sudrajat, } \\
\text { S.Pd. }\end{array}$ & SMP Sukamaju & $\begin{array}{l}\text { Saya sangat berterima kasih atas } \\
\text { terselenggaranya kegiatan workshop ini, } \\
\text { karena melalui kegiatan ini semakin } \\
\text { memotivasi para guru untuk meningkatkan } \\
\text { kompetensinya melalui penulisan karya } \\
\text { ilmiah, terutama pelaksanaan PTK. } \\
\text { Kegiatan workshop ini perlu tindak lanjut } \\
\text { sebagai salah satu cara dalam peningkatan } \\
\text { kualitas dan profesionalitas guru. }\end{array}$ \\
\hline
\end{tabular}

\section{B. Pembahasan}

Peningkatan pemahaman mengenai PTK adalah meningkatkan penguasaan informasi dan ilmu pengetahuan serta menerapkan ilmu pengetahuan tentang perbaikan mutu melalui penggunaan cara berpikir ilmiah. Peningkatan keterampilan melaksanakan PTK merupakan bagian dari peningkatan kemampuan profesi bagi peningkatan efektivitas belajar.

Untuk mencapai kondisi yang diharapkan tersebut, Suharsimi (2008) menyatakan bahwa dalam melaksanakan PTK seorang guru perlu meningkatkan keterampilan dalam 
melaksanakan empat langkah utama dalam siklus penerapan berpikir ilmiah, yaitu: (1) melaksanakan observasi; (2) merumuskan masalah atau hipotesis; (3) melaksanakan penelitian tindakan; dan (4) mengevaluasi tindakan. Langkah pelaksanaan PTK tersebut dapat digambarkan secara lengkap dalam Gambar 1.

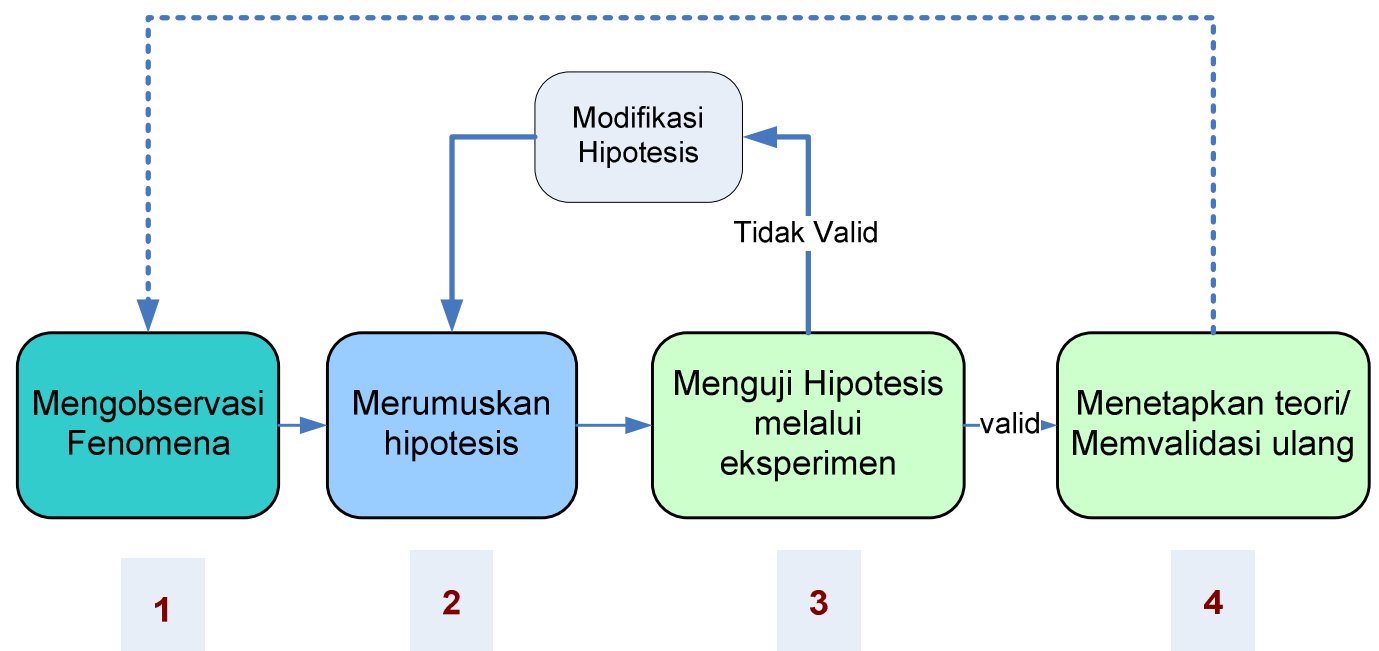

Gambar 1. Langkah-langkah PTK

Karena penelitian tindakan kelas merupakan model laporan pelaksanaan tugas yang menggunakan pendekatan ilmiah, maka sebagian ahli menyatakan bahwa dalam sistem berpikir PTK tidak memerlukan hipotesis. Dengan mengunakan pendekatan program lazim menggunakan masalah untuk menyatakan kesenjangan antara kondisi nyata dengan kondisi yang diharapkan.

Untuk mencapai tujuan tersebut, Kasihani (1998) menyatakan bahwa skenario kegiatan simulasi pelaksanaan PTK terbagi dalam enam tahap:

Bagian Pertama : Diskusi tentang PTK dan simulasi observasi pra-PTK.

Bagian Kedua $\quad$ : Deskripsi kondisi ideal dan kondisi nyata

Bagian Ketiga $\quad$ : Deskripsi masalah dan alternatif solusi

Bagian Keempat : Proposal

Bagian Kelima : Pelaksanaan dan evaluasi PTK

Bagian Keenam : Penyusunan laporan karya tulis ilmiah

\section{KESIMPULAN DAN SARAN}

\section{Kesimpulan}

Kesimpulan dari kegiatan workshop Peningkatan Profesionalitas Guru Matematika melalui Penulisan Karya Ilmiah adalah: 
1. Kegiatan workshop ini, semakin memotivasi para guru untuk meningkatkan kompetensi dan profesionalitasnya melalui penulisan karya ilmiah terutama PTK. Karena tugas utama guru adalah mendidik, mengajar, membimbing, mengarahkan, melatih, menilai, dan mengevaluasi peserta didik.

2. Workshop penulisan karya ilmiah menambah pengetahuan guru matematika untuk melaksanakan PTK dengan tujuan untuk meningkatkan kualitas pembelajaran.

3. Workshop dirasakan manfaatnya oleh peserta workshop dan diharapkan dapat meningkatkan kualitas pembelajaran matematika di sekolah.

\section{Saran}

Beberapa saran dari kegiatan pengabdian ini adalah:

1. Perlu pembinaan lebih lanjut, agar para guru dapat mengoptimalkan kemampuan untuk menulis karya ilmiah (meningkatkan kompetensi dan profesionalitasnya).

2. Pelaksanaan workshop dapat diperluas jangkauannya ke guru matematika di komisariat lainnya di Kabupaten Ciamis.

3. Acara workshop dapat dilaksanakan dalam durasi lebih lama, sehingga guru dapat lebih leluasa pada kegiatan simulasi pembuatan karya ilmiah.

4. Kegiatan yang dilaksanakan oleh dosen Prodi Pendidikan Matematika FKIP UNIGAL dengan sasaran para guru matematika diharapkan dapat dilanjutkan dengan kegiatankegiatan yang lainnya yang dibutuhkan oleh guru matematika.

\section{UCAPAN TERIMA KASIH}

Penulis menyampaikan ucapan terima kasih yang sebesar-besarnya kepada Lembaga Penelitian dan Pengabdian Kepada Masyarakat (LPPM) Universitas Galuh yang telah membiayai kegiatan pengabdian ini.

\section{DAFTAR PUSTAKA}

Depdiknas. (2005). Penulisan Karya Ilmiah dalam Materi Pelatihan Terintegrasi Jilid 3.Jakarta: Depdiknas Dirjen Pendidikan Dasar dan Menengah Direktorat Pendidikan Lanjutan Pertama.

Kasihani, K. (1998). Penelitian Tindakan Kelas. Jakarta: Depdiknas.

Kunandar. (2013). Langkah Mudah Penelitian Tindakan Kelas sebagai Pengembangan Profesi Guru, Jakarta: PT RajaGrafindo Persada.

Mulyasa, E. (2008). Standar Kompetensi dan Sertifikasi Guru, Bandung: PT. Remaja Rosda Karya. 
Peraturan Menteri Pendayagunaan Aparatur Negara dan Reformasi Birokrasi Nonor 16 Tahun 2009, tanggal 10 November 2009, tentang Jabatan Fungsional Guru dan Angka Kreditnya.

Suharsimi, Suhardjono, dan Supardi. (2008). Penelitian Tindakan Kelas. Jakarta: PT. Bumi Aksara.

Sukanti. (2008). Meningkatkan Kompetensi Guru melalui Pelaksanaan Penelitian Tindakan Kelas. Jurnal Pendidikan Akuntansi Indonesia, VI(1): 1-11.

Usman, M. U. (2006). Menjadi Guru Profesional, Bandung: PT. Remaja Rosda Karya, Cet. Ke- 20. 